\title{
Childhood-onset granulomatosis with polyangiitis and microscopic polyangiitis: systematic review and meta-analysis
}

\author{
Michele ludici ${ }^{1,2}$, Pierre Quartier ${ }^{3}$, Benjamin Terrier ${ }^{1}$, Luc Mouthon $^{1}$, Loïc Guillevin ${ }^{1}$ and Xavier Puéchal ${ }^{1 *}$ (D)
}

\begin{abstract}
Background: The data from cohorts of childhood-onset granulomatosis with polyangiitis (GPA) and microscopic polyangiitis (MPA) remain scarce and heterogeneous. We aimed to analyse the features at presentation, therapeutic approaches and the disease course of these rare diseases.

Methods: Electronic searches of Medline and the Cochrane Central Register of Controlled trials database were conducted. We also checked the reference lists of the studies included and other systematic reviews, to identify additional reports. We included all cohorts, cross-sectional studies or registries reporting features at presentation or outcomes in patients with a diagnosis of childhood-onset GPA or MPA (age <18 years). The pooled prevalence of clinical manifestations at presentation, ANCA and induction therapies for GPA and MPA was calculated.

Results: We reviewed 570 full texts and identified 14 studies on GPA and 8 on MPA. Childhood-onset GPA and MPA occurred predominantly in female subjects during adolescence. For GPA, ear-nose-throat (ENT) disease (pooled prevalence $82 \%$ [95 \% Cl 78-87]), constitutional symptoms (73\% [95 \% Cl 55-88]), renal (65\% [95 \% Cl 49-79]), and lower respiratory tract $(61 \%$ [95 \% Cl 48-74]) manifestations were the most frequently reported at presentation. Renal disease was a hallmark of MPA (94\% [95\% Cl 89-97]). ANCA were detected in >90 \% of children with GPA or MPA. Combined corticosteroids and cyclophosphamide was the most frequently used first remission-inducing treatment for GPA (76 \% [95 \% Cl 69-82]) and MPA (62 \% [95 \% Cl 20-96]). Relapses occurred more frequently in GPA (67-100 \%) than in MPA (25-50\%). The leading causes of death were the disease itself, and infections.
\end{abstract}

Conclusions: Childhood-onset MPA and GPA remain severe diseases with frequent relapses and a high cumulative morbidity. Survival and disease-free survival need to be improved.

Keywords: Granulomatosis with polyangiitis, Microscopic polyangiitis, Paediatrics

\section{Background}

Systemic vasculitis in children accounts for 2 to $10 \%$ of the conditions evaluated in paediatric rheumatology clinics $[1,2]$. IgA vasculitis and Kawasaki disease are the most common [3], whereas childhood-onset antineutrophil cytoplasmic antibody (ANCA)-associated vasculitis (AAV), including granulomatosis with polyangiitis

\footnotetext{
* Correspondence: xavier.puechal@aphp.fr

${ }^{1}$ National Referral Center for Rare Systemic Autoimmune Diseases, Department of Internal Medicine, Hôpital Cochin, Assistance PubliqueHôpitaux de Paris (APHP), Université Paris Descartes, Paris, France Full list of author information is available at the end of the article
}

(GPA, Wegener's), eosinophilic granulomatosis with polyangiitis (EGPA, Churg-Strauss) and microscopic polyangiitis (MPA) are more rare. Our knowledge of these diseases is based mostly on small cohort studies or, more frequently, case series or reports. Since the development of the first specific paediatric classification of vasculitis by the European League Against Rheumatism (EULAR) and the Paediatric Rheumatology European Society (PReS) in 2006 [4], the number of cohorts of patients with paediatric AAV, mostly GPA, reported has steadily increased [5-12].

Nevertheless, the data from such cohorts remain scarce and heterogeneous, and no attempt has yet been 
made to outline the main features of these rare diseases more precisely.

We conducted a systematic literature review and meta-analysis: 1 ) to summarize the principal clinical and demographic features on presentation; 2) to describe the course of the disease and 3) to describe the therapeutic approaches reported for children with GPA and MPA.

\section{Methods}

Literature search

We performed a systematic literature review and a metaanalysis, to obtain a best estimate of the prevalence of clinical manifestations at presentation and to review the treatments given to patients with childhood-onset GPA and MPA. The Meta-analyses of Observational Studies in Epidemiology (MOOSE) guidelines were followed [13]. We conducted a literature search on Medline and the Cochrane Central Register of Controlled trials database from January 1, 1950 to December 31, 2015, as reported on Additional file 1. We also checked the reference lists of the studies included and other systematic reviews on the topic, to identify additional reports.

\section{Inclusion criteria and procedure}

We included all cohorts, cross-sectional studies or registries reporting data for features at presentation or outcomes in patients with a diagnosis of childhood-onset GPA or MPA (age < 18 years). All papers providing a baseline description of the study population were considered. Studies reporting only data for specific subgroups of patients (e.g. only patients with nephritis) were excluded.

The titles and abstracts of all the references identified were reviewed independently by two of the authors (MI, $\mathrm{XP})$. The full text of the articles considered potentially relevant was then screened and checked for eligibility. Any disagreements about article inclusion were resolved at this stage.

\section{Data extraction}

We used standardized data extraction forms. We recorded the clinical manifestations at diagnosis, and the number of patients with at least one clinical manifestation within each organ/system domain, if specified. If the authors reported only the number of patients with a particular single clinical manifestation but not the sum of patients with at least one manifestation within a domain (e.g. the number of patients with lung nodules etc., but not the total number of patients with respiratory involvement), we used the lowest estimate for the pooling of prevalence data. Clinical manifestations that were not described were considered to be absent.

Remission and relapses were defined according to EULAR recommendations [14]. We checked the accuracy of data extraction, and any inconsistencies were discussed and resolved.

\section{Quality scoring}

Two authors independently rated each paper for the risk of bias, based on the Methodological Evaluation of Observational research checklist, which was adapted for the specific research question [15] (Additional file 2).

\section{Statistical analyses}

All point estimates of analyses and their $95 \%$ confidence intervals $(95 \% \mathrm{CI})$ were calculated by inverse variance weighting. Heterogeneity was assessed by carrying out $\chi^{2}$ tests on Cochran's $Q$ statistic and by calculating $I^{2}$. If heterogeneity was high $\left(\mathrm{I}^{2}>50 \%\right)$, we used random-effect models. Forest plots were constructed. We considered $p$ values $<0.05$ to be statistically significant. Data were analysed with MetaXL (MetaXL 1.3, EpiGear International Brisbane). We did not use funnel plots to assess publication bias because this technique was not applicable [16].

\section{Results}

Literature search

The literature search identified 570 hits in PubMed, and 0 in the Cochrane Library (Additional file 3). Thirtythree articles were considered to be potentially relevant. Another 12 potentially relevant articles were identified by an additional search and by screening the references of the included articles. Overall, we included 14 studies on GPA and eight on MPA.

\section{Granulomatosis with polyangiitis \\ Characteristics of the studies included}

We analysed data from 13 retrospective studies [5-7, 9-12, 17-22] and one prospective cohort [23]. One study included two 20-year-old patients [17] and another used an upper limit of 19 years for the definition of childhood-onset AAV [23], but we decided to retain these studies in the analysis to prevent the loss of useful information. In total, data for 294 patients (69 \% girls) were included. The main characteristics of studies included are summarised in Table 1.

\section{Risk of bias}

The most frequent sources of bias were the sampling framework and the case definition for GPA, followed by patient selection (Additional file 2: Tables S1 and S2).

\section{Clinical and laboratory features on entry into the study}

Thirteen of the 14 studies included assessed the features of the patients on entry into the study $[5-7,9-12,17-19$, 21-23]. These studies included 277 patients in total: 145/ 194 (75 \%) were Caucasian (data available for seven studies), with a median age at disease onset of 11.6 years (data available for seven studies) and a median age at diagnosis 
Table 1 Main characteristics of the studies on childhood-onset granulomatosis with polyangiitis and features of the patients at presentation

\begin{tabular}{|c|c|c|c|c|c|c|c|c|c|c|c|c|c|}
\hline First author & $\begin{array}{l}\text { Stegmayr } \\
{[20]}\end{array}$ & $\begin{array}{l}\text { Cabral } \\
{[6]}\end{array}$ & $\begin{array}{l}\text { Rottem } \\
{[24]}\end{array}$ & Akikusa [5] & $\begin{array}{l}\text { Tahghighi } \\
\text { [22] }\end{array}$ & $\begin{array}{l}\text { Gajic-Veljic } \\
\text { [23] }\end{array}$ & $\begin{array}{l}\text { ludici } \\
\text { [11] }\end{array}$ & $\begin{array}{l}\text { Sacri } \\
\text { [12] }\end{array}$ & $\begin{array}{l}\text { Arulkumaran } \\
{[7]}\end{array}$ & $\begin{array}{l}\text { Wong } \\
{[19]}\end{array}$ & $\begin{array}{l}\text { Orlowski } \\
{[18]}\end{array}$ & $\begin{array}{l}\text { Bohm } \\
{[9]}\end{array}$ & $\begin{array}{l}\text { Kosalka } \\
{[10]}\end{array}$ \\
\hline Speciality & $\begin{array}{l}\text { Paediatric } \\
\text { Nephrology }\end{array}$ & $\begin{array}{l}\text { Paediatric } \\
\text { Rheumatology }\end{array}$ & Paediatrics & $\begin{array}{l}\text { Paediatric } \\
\text { Rheumatology }\end{array}$ & $\begin{array}{l}\text { Paediatric } \\
\text { Rheumatology }\end{array}$ & $\begin{array}{l}\text { Paediatric } \\
\text { Dermatology }\end{array}$ & $\begin{array}{l}\text { Adult } \\
\text { Internal } \\
\text { Medicine }\end{array}$ & $\begin{array}{l}\text { Paediatric } \\
\text { Nephrology } \\
\text { and } \\
\text { Rheumatology }\end{array}$ & $\begin{array}{l}\text { Adult } \\
\text { Rheumatology }\end{array}$ & Paediatrics & Paediatrics & Paediatrics & Paediatrics \\
\hline Country & $\begin{array}{l}\text { Sweden, } \\
\text { Germany }\end{array}$ & $\begin{array}{l}\text { USA, } \\
\text { Canada }\end{array}$ & USA & Canada & Iran & Serbia & France & France & UK & UK & USA & International & Poland \\
\hline $\begin{array}{l}\text { Year of } \\
\text { publication }\end{array}$ & 2000 & 2009 & 1993 & 2007 & 2013 & 2013 & 2015 & 2015 & 2011 & 1998 & 1978 & 2014 & 2014 \\
\hline $\begin{array}{l}\text { Years of } \\
\text { enrolment }\end{array}$ & NA & since 2004 & NA & 1984-2005 & 2002-2011 & 1992-2011 & $1965-2014$ & 1986-2011 & 1996-2010 & 1986-1991 & 1952-1976 & $2000-2010$ & 1995-2013 \\
\hline Study design & Retrospective & $\begin{array}{l}\text { Cross-sectional } \\
\text { 2004-2007: } \\
\text { retrospectively } \\
\text { collected } \\
\text { March 2007- } \\
\text { November 2008: } \\
\text { prospectively } \\
\text { collected }\end{array}$ & Prospective & Retrospective & $\begin{array}{l}\text { Cross- } \\
\text { sectional } \\
\text { Retrospective }\end{array}$ & Retrospective & Retrospective & Retrospective & Retrospective & Retrospective & Retrospective & Retrospective & Retrospective \\
\hline $\begin{array}{l}\text { Number of } \\
\text { patients }\end{array}$ & 7 & 65 & 23 & 25 & 11 & 3 & 25 & 28 & 7 & 12 & 6 & 56 & 9 \\
\hline Ethnicity $(n)$ & Caucasian & $\begin{array}{l}41 \text { Caucasian, } \\
4 \text { mixed, } 3 \text { East } \\
\text { Indian, } 3 \text { African } \\
\text { American, } \\
2 \text { Hispanic, } 1 \\
\text { Asian, } 1 \text { Middle } \\
\text { Eastern, } 6 \text { not } \\
\text { available }\end{array}$ & NA & White $21 / 25$ & NA & NA & $\begin{array}{l}19 \\
\text { Caucasian }\end{array}$ & 21 Caucasian & $\begin{array}{l}5 \text { Caucasian, } \\
2 \text { Afro- } \\
\text { Carribean }\end{array}$ & NA & 6 Caucasians & $\begin{array}{l}46 \\
\text { Caucasian }\end{array}$ & NA \\
\hline$F(n)$ & 3 & 43 & 16 & 20 & 5 & 3 & 18 & 21 & 5 & 8 & 3 & 38 & 6 \\
\hline $\begin{array}{l}\text { Median age } \\
\text { at onset } \\
\text { (range), } \\
\text { years }\end{array}$ & NA & NA & $15.4(9.3-19.4)$ & NA & NA & $11(6-16)$ & NA & NA & $11.5(9-15)$ & $9(0.5-14)$ & $17(13-20)$ & $\begin{array}{l}11.7 \text { (1st } \\
\text { and 3rd } \\
\text { quartile } \\
8.5-14.5)\end{array}$ & $12(88-16)$ \\
\hline $\begin{array}{l}\text { Median age } \\
\text { at diagnosis } \\
\text { (range), years }\end{array}$ & 14 (11-18) & $14.2(4-17)$ & & $\begin{array}{l}14.5 \\
(8.7-17.1)\end{array}$ & $11(6-15)$ & & $14(2-17)$ & $\begin{array}{l}12.8 \\
(10.1-14.6)\end{array}$ & & & & & \\
\hline $\begin{array}{l}\text { Classification/ } \\
\text { diagnostic tool } \\
\text { used }\end{array}$ & $\begin{array}{l}\text { Presence of } \\
\text { kidney biopsy, } \\
\text { upper } \\
\text { and lower } \\
\text { respiratory } \\
\text { tract disease, } \\
\text { ANCA+ }\end{array}$ & MD diagnosis & $\begin{array}{l}\text { Clinical history } \\
\text { compatible } \\
\text { with GPA and } \\
\text { histopathological } \\
\text { evidence of } \\
\text { vasculitis or } \\
\text { granulomas, } \\
\text { or both }\end{array}$ & $\begin{array}{l}\text { ACR } \\
\text { Criteria }\end{array}$ & $\begin{array}{l}\text { EULAR/ } \\
\text { PRINTO/ } \\
\text { PRES }\end{array}$ & $\begin{array}{l}\text { Clinical history } \\
\text { compatible } \\
\text { with GPA and } \\
\text { histo- } \\
\text { pathological } \\
\text { evidence of } \\
\text { vasculitis or } \\
\text { granulomas, } \\
\text { or both }\end{array}$ & $\begin{array}{l}\text { EULAR/ } \\
\text { PRINTO/ } \\
\text { PRES and } \\
\text { Revised } \\
\text { Chapel-Hill }\end{array}$ & $\begin{array}{l}\text { EULAR/ } \\
\text { PRINTO/ } \\
\text { PRES }\end{array}$ & $\begin{array}{l}\text { EULAR/ } \\
\text { PRINTO/ } \\
\text { PRES }\end{array}$ & ACR Criteria & $\begin{array}{l}\text { Histological } \\
\text { examination } \\
\text { in all } \\
\text { patients }\end{array}$ & $\begin{array}{l}\text { EULAR/ } \\
\text { PRINTO/ } \\
\text { PRES }\end{array}$ & $\begin{array}{l}\text { EULAR/ } \\
\text { PRINTO/ } \\
\text { PRES or } \\
\text { ACR } \\
\text { criteria }\end{array}$ \\
\hline $\begin{array}{l}\text { CANCA positivity } \\
\text { (ELISA), } n(\%)\end{array}$ & $6 / 7(85.7)$ & $43(66.2)$ & NA & 13/15 (86.7) & $11(100)$ & $2(66.6)$ & 10/18 (55.5) & $18 / 28(64.2)$ & NA & $4(33.3)$ & NA & 34/51 (66.6) & NA \\
\hline
\end{tabular}


Table 1 Main characteristics of the studies on childhood-onset granulomatosis with polyangiitis and features of the patients at presentation (Continued)

\begin{tabular}{|c|c|c|c|c|c|c|c|c|c|c|c|c|c|}
\hline $\begin{array}{l}\text { pANCA positivity } \\
\text { (ELISA), } n(\%)\end{array}$ & $1 / 7(14.2)$ & $8(12.3)$ & NA & NA & $2(18)$ & $1(33.3)$ & $4 / 18(22.2)$ & $6 / 28(21.4)$ & NA & $6(50.0)$ & NA & $13 / 50(26.0)$ & $\mathrm{NA}$ \\
\hline $\begin{array}{l}\text { CANCA positivity } \\
(\mathrm{IFI}), n(\%)\end{array}$ & NA & $43(66.2)$ & NA & 13/15 (86.7) & $11(100)$ & $2(66.6)$ & $12 / 20(60.0)$ & NA & $4 / 7(57.1)$ & $6(50.0)$ & NA & NA & NA \\
\hline $\begin{array}{l}\text { pANCA positivity } \\
(|| F \mid), n(\%)\end{array}$ & NA & $14(21.5)$ & NA & 2/15 (13.3) & NA & $1(33.3)$ & $4 / 20(20.0)$ & NA & $1 / 7(14.2)$ & $1(14.2)$ & NA & NA & NA \\
\hline \multicolumn{14}{|l|}{$\begin{array}{l}\text { Clinical } \\
\text { manifestations }\end{array}$} \\
\hline $\begin{array}{l}\text { Systemic, } \\
n(\%)\end{array}$ & $7(100)$ & $58(89.2)$ & $5(71.4)$ & $24(96.0)$ & $9(81.8)$ & $3(100)$ & $17(68.0)$ & $23(82.1)$ & $3(42.8)$ & 0 & $5(83.3)$ & $50(89.2)$ & $8(88.8)$ \\
\hline $\begin{array}{l}\text { Mucocutaneous, } \\
n(\%)\end{array}$ & $2(28.5)$ & $23(35.4)$ & $2(8.6)$ & $8(32.0)$ & $3(27.2)$ & $3(100)$ & $6(24.0)$ & $15(53.5)$ & $4(57.1)$ & $10(83.3)$ & $3(50.0)$ & $36(64.2)$ & $4(44.4)$ \\
\hline $\begin{array}{l}\text { Musculoskeletal, } \\
n(\%)\end{array}$ & $4(57.1)$ & $37(56.9)$ & $7(30.4)$ & $24(96.0)$ & $3(27.2)$ & $2(66.6)$ & $9(36.0)$ & $16(57.1)$ & $5(71.4)$ & $9(75.0)$ & $2(33.3)$ & $33(58.9)$ & $3(33.3)$ \\
\hline Ocular, n (\%) & 0 & $24(36.9)$ & $3(13.0)$ & $13(52.0)$ & $2(18.8)$ & $2(66.6)$ & $7(28.0)$ & $6(21.4)$ & $3(42.8)$ & 0 & $1(16.6)$ & $19(33.9)$ & $1(11.1)$ \\
\hline $\begin{array}{l}\text { Ear, nose, } \\
\text { and throat, } \\
n(\%)\end{array}$ & $7(100)$ & $52(80.0)$ & $20(87)$ & $21(84.0)$ & $8(72.7)$ & $2(33.3)$ & $21(84.0)$ & $21(75.0)$ & $4(57.1)$ & $11(91.6)$ & $6(100)$ & $51(91.0)$ & $5(55.5)$ \\
\hline $\begin{array}{l}\text { Respiratory, } \\
n(\%)\end{array}$ & $6(85.7)$ & $52(80.0)$ & $5(21.7)$ & $20(80.0)$ & $2(18.1)$ & 0 & $17(68.0)$ & $19(67.8)$ & $3(42.8)$ & $7(58.3)$ & $5(83.3)$ & $44(78.5)$ & $7(77.7)$ \\
\hline $\begin{array}{l}\text { Cardiovascular, } \\
n(\%)\end{array}$ & 0 & 0 & $2(8.7)$ & $5(20.0)$ & $1(9.0)$ & 0 & 0 & 0 & 0 & 0 & 0 & 0 & 0 \\
\hline $\begin{array}{l}\text { Gastrointestinal, } \\
n(\%)\end{array}$ & 0 & $27(41.5)$ & 0 & $3(12.0)$ & $3(27.2)$ & 0 & $5(20.0)$ & $5(17.8)$ & $1(14.2)$ & $6(50.0)$ & 0 & $9(16.0)$ & $5(55.5)$ \\
\hline $\begin{array}{l}\text { Neurological, } \\
\text { n (\%) }\end{array}$ & 0 & $16(24.6)$ & $1(4.3)$ & $2(8.0)$ & $1(9.0)$ & 0 & $1(4.0)$ & $1(3.5)$ & $1(14.2)$ & $2(16.6)$ & $1(16.6)$ & $8(14.2)$ & $1(11.1)$ \\
\hline Renal, $n$ (\%) & $7(100)$ & $49(75.4)$ & $2(8.6)$ & $22(88.0)$ & $4(36.3)$ & $3(100)$ & $9(36.0)$ & $22(78.5)$ & $4(57.1)$ & $4(33.3)$ & $5(83.3)$ & $38(67.8)$ & $8(88.8)$ \\
\hline \multicolumn{14}{|l|}{ Treatment } \\
\hline $\begin{array}{l}\text { Oral GCs } \pm \mathrm{IS}, \\
n(\%)\end{array}$ & $7(100)$ & $60(92.3)$ & $23(100)$ & $25(100)$ & NA & $3(100)$ & $21(84.0)$ & $28(100)$ & NA & NA & $5(83.3)$ & NA & $9(100)$ \\
\hline $\begin{array}{l}\text { GCs } \pm \text { CYC, } \\
n(\%)\end{array}$ & $6(85.7)$ & $54(83.0)$ & $18(78.2)$ & $15(60.0)$ & NA & $3(100)$ & $18(72.0)$ & NA & NA & NA & $3(50.0)$ & NA & $9(100)$ \\
\hline $\begin{array}{l}\mathrm{GCs} \pm \mathrm{MTX} \\
n(\%)\end{array}$ & 0 & $7(10.7)$ & $1(4.3)$ & $5(20.0)$ & NA & 0 & $2(8.0)$ & NA & NA & NA & 0 & NA & 0 \\
\hline $\begin{array}{l}\text { GCs } \pm A Z A, \\
n(\%)\end{array}$ & 0 & 0 & $2(8.6)$ & 0 & NA & 0 & $2(8.0)$ & NA & NA & NA & 0 & NA & 0 \\
\hline $\begin{array}{l}\text { Plasmapheresis, } \\
n(\%)\end{array}$ & $4(57.1)$ & $9(13.8)$ & 0 & 0 & NA & $1(33.3)$ & $1(4.0)$ & NA & NA & NA & 0 & NA & 0 \\
\hline
\end{tabular}
with polyangiitis 
of 14 years (range: 4-17) (data available for six studies). Prevalence for the involvement of each organ/system is shown in Table 2.

ENT system involvement was the most frequent manifestation observed, followed by constitutional symptoms, renal, lower respiratory tract, musculoskeletal and cutaneous involvement (Fig. 1). Mild heterogeneity was observed only for ENT and neurologic involvement.

None of the patients had baseline gangrene or retinal vasculitis, two of the "major" clinical manifestations according to the modified Birmingham Vasculitis Activity Score [24]. CNS (central nervous system) involvement occurred in $3 \%$ (95\% CI 1-7 \%; $\mathrm{I}^{2}=31 \%$ ) of patients, but no detailed information was provided. Other major manifestations included scleritis/episcleritis in $2 \%$ (95\% CI 1-4 \%; $\mathrm{I}^{2}=43 \%$ ), ischemic abdominal pain in $2 \%$ (95\% CI 1-4 \%; $\left.\mathrm{I}^{2}=64 \%\right)$, haemoptysis/alveolar haemorrhage in $16 \%$ (95 \% CI 6$29 \% ; \mathrm{I}^{2}=84 \%$ ), and renal problems requiring dialysis in $2 \%\left(95 \%\right.$ CI $1-5 \%$; $\left.\mathrm{I}^{2}=48 \%\right)$ of patients. Subglottic stenosis and saddle nose were observed at presentation in $9 \%$ $\left(95 \%\right.$ CI $\left.6-12 \% ; \mathrm{I}^{2}=0 \%\right)$ and $5 \%\left(95 \%\right.$ CI $1-11 \% ; \mathrm{I}^{2}=$ $64 \%)$ of patients, respectively, and lung nodules were observed in $10 \%$ of patients (95\% CI 2-22\%; $\mathrm{I}^{2}=84 \%$ ).

A sensitivity analysis was performed. We first excluded the two studies including adult patients $[7,11]$, with no major impact on prevalence estimates and then the nephrology surveys $[12,19]$, resulting in a lower prevalence of renal disease at admission (Additional file 4: Table S5). Following the grouping of studies by geographic origin (Europe or North America), we found that the prevalence of skin manifestations was higher in Europe (prevalence $55 \%$ [95 \% CI 32-76] vs. $28 \%$ [95\% CI $14-45 \%] ; p=0.01)[7,10-12,18,19,22]$, whereas the prevalence of neurological involvement was higher in studies from North America [5, 6, 17, 23] (17 \% [95 \% CI $10-24]$ vs. $7 \%$ [95 \% CI 2-14]; $p=0.043$ ).

Seven studies provided information about ANCA detection by immunofluorescence methods $[5-7,11,17$,
21, 22]. Positive results were obtained for c-ANCA in $71 \%\left(95 \%\right.$ CI $\left.56-84, \mathrm{I}^{2}=59 \%\right)$, and for p-ANCA in $20 \%\left(95 \%\right.$ CI $\left.13-27, \mathrm{I}^{2}=0 \%\right)$ of patients. The estimated prevalence of anti-PR3 (proteinase 3) antibodies was $69 \%$ (95\% CI 58-80, $\left.\mathrm{I}^{2}=60 \%\right)$, whereas that of anti-MPO (myeloperoxidase) antibodies was $21 \%$ (95\% CI $16-27, \mathrm{I}^{2}=25 \%$ ) (data available from 9 studies) [5, 6, $9,11,12,18,19,21,22]$.

\section{Induction therapies and drug-related adverse events}

The drugs used for induction therapy were reported in nine studies [5, 6, 10-12, 17, 19, 22, 23]. Corticosteroids were the most prescribed drugs (prevalence $95 \%$; $95 \%$ CI 92-98; $\mathrm{I}^{2}=35 \%$ ), but it was not possible to determine the dose most frequently used. Immunosuppressants were also used (in monotherapy or with corticosteroids): cyclophosphamide in $76 \%\left(95 \%\right.$ CI $\left.69-82 ; \mathrm{I}^{2}=27 \%\right)$ of patients, methotrexate in $10 \%\left(95 \%\right.$ CI $\left.6-16 ; \mathrm{I}^{2}=0 \%\right)$, azathioprine in $2 \%\left(95 \% \mathrm{CI} 0-5 ; \mathrm{I}^{2}=26 \%\right)$ and plasmapheresis in $8 \%$ of patients ( $95 \%$ CI $1-21 ; \mathrm{I}^{2}=72 \%$ ). With the exception of plasmapheresis, immunosuppression protocols were very similar between studies. The other drugs used for induction therapy included immunoglobulins, cyclosporine, colchicine and rituximab.

The principal drug-related adverse events reported were infections. Infertility, hemorragic cystitis, cataracts, glaucoma, osteoporosis, steroid myopathy, Cushing syndrome, and depression were also reported. Growth retardation was observed in two studies [5, 20], but not confirmed in a third one [11]. Only one case of breast cancer diagnosed at age of 30 was reported.

\section{Follow-up data for cumulative clinical manifestations, relapse, and survival}

At least one item of information about the course of the disease was reported in 11 articles [5, 7, 10-12, 17, 19-23]. The duration of the observation period was reported in four studies, and ranged from 2.7 to 18.5 years $[5,7,11,23]$. At

Table 2 Prevalence for the involvement of each organ/system at first consultation in childhood-onset granulomatosis with polyangiitis and microscopic polyangiitis

\begin{tabular}{|c|c|c|c|c|c|c|c|c|c|c|}
\hline Organ/system & ENT & Systemic & Renal & $\begin{array}{l}\text { Lower respiratory } \\
\text { tract }\end{array}$ & Musculoskeletal & Cutaneous & Ocular & Gastrointestinal & Neurological & Cardiovascular \\
\hline \multicolumn{11}{|l|}{ GPA } \\
\hline $\begin{array}{l}\text { Pooled } \\
\text { prevalence }\end{array}$ & 82 & 73 & 65 & 61 & 55 & 44 & 24 & 19 & 13 & 4 \\
\hline $95 \% \mathrm{Cl}$ & $78-87$ & $55-88$ & $49-79$ & $48-74$ & $43-67$ & $32-57$ & $15-34$ & $10-30$ & $9-17$ & $1-9$ \\
\hline $1^{2}$ & 26 & 88 & 84 & 77 & 72 & 75 & 64 & 72 & 15 & 61 \\
\hline \multicolumn{11}{|l|}{ MPA } \\
\hline $\begin{array}{l}\text { Pooled } \\
\text { prevalence }\end{array}$ & 3 & 79 & 94 & 37 & 57 & 44 & 7 & 28 & 18 & 2 \\
\hline $95 \%$ Cl & $1-7$ & $65-90$ & 89-97 & $24-52$ & $27-86$ & $27-61$ & $3-11$ & $17-41$ & $7-34$ & $0-5$ \\
\hline $1^{2}$ & 0 & 64 & 47 & 67 & 89 & 73 & 0 & 55 & 72 & 0 \\
\hline
\end{tabular}




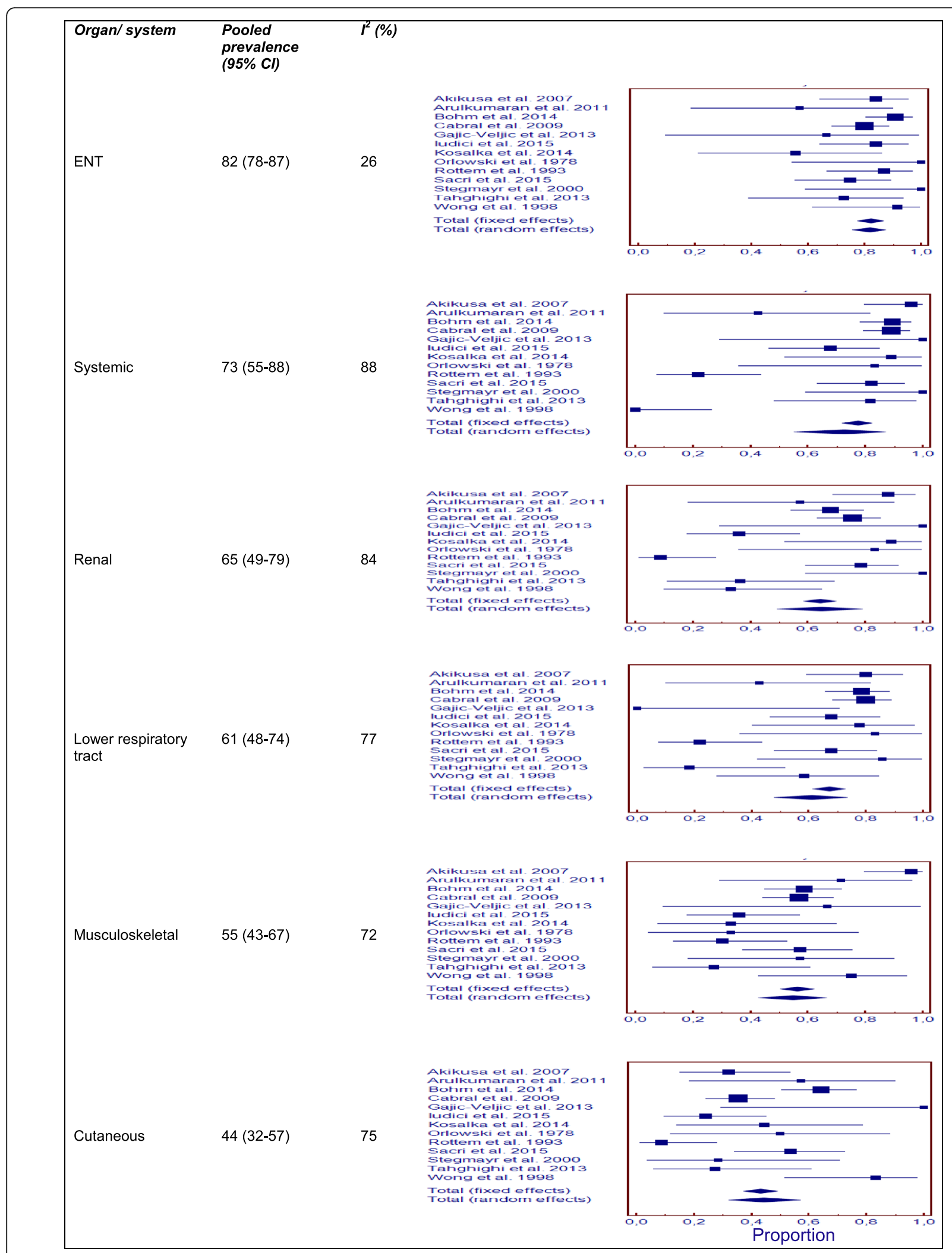

Fig. 1 Pooled prevalence for the most frequent organ/system involvement at first consultation in childhood-onset granulomatosis with polyangiitis 
least one relapse occurred in 67 to $100 \%$ of patients. Survival data were available for 161 patients: 14 of these patients died (at a mean age $( \pm$ SD) of $18 \pm 11$ years; based on data for eight patients), from sepsis in two patients, fungal infection in one, pulmonary haemorrhage in three, chronic lung disease due to GPA in two, multiple-organ failure in one, and a heroin overdose in one. Cumulative incidence was 91 to $100 \%$ for ENT involvement, up to $48 \%$ for subglottic stenosis, up to $60 \%$ for ocular disease and up to $88 \%$ for renal involvement.

\section{Microscopic polyangiitis}

Literature search and characteristics of the studies included

We analysed data from eight retrospective cohorts $[11,12$, 25-30] for a total of 130 patients (86/109 patients were female [79 \%]). The main organ/system involvement are summarised in Table 2 and the main characteristics of studies included in Table 3.

\section{Risk of bias}

The most frequent source of bias was the sampling framework for MPA, followed by patient selection and the definition of MPA (Additional file 2: Tables S3 and S4).

\section{Clinical and laboratory features on entry into the study}

For the 130 MPA patients identified, median age was 10.5 years at disease onset (data available for four studies) and 12 years at diagnosis (data available for three studies).

Renal disease was the most frequent manifestation on presentation, followed by systemic features, musculoskeletal, cutaneous, lower respiratory tract and gastrointestinal system involvement (Table 2). Heterogeneity between studies was low for renal, ENT, ocular, and cardiovascular involvement (Fig. 2). Lung infiltrates (18\% [95 \% CI 6-35]; $\mathrm{I}^{2}=$ $77 \%)$ and alveolar haemorrhage (18\%, [95 \% CI 5-35]; $\mathrm{I}^{2}=$ $77 \%)$ occurred at similar frequencies. ENT involvement was limited to sinusitis. Seizures were the most frequent neurological manifestation (5 \% [95 \% CI 2-9]; $\mathrm{I}^{2}=44 \%$ ) and purpura was the most frequent skin lesion (10\% [95\% CI 0-27]; $\mathrm{I}^{2}=86 \%$ ).

Following the grouping of the studies by geographic region of origin (Europe or Asia), we found that the prevalence of skin manifestations (66\% [95\% CI 28-96] vs. $29 \%$ [95 \% CI 19-40]; $p=0.02$ ) was higher in studies from Europe [11, 12, 25, 27] (Additional file 4: Table S6).

Information about immunofluorescence findings for ANCA positivity was available in five studies [11, 25, 28-30]. Positive results were obtained for c-ANCA in $4 \%$ of patients (95\% CI $1-11, \mathrm{I}^{2}=50 \%$ ), and for $\mathrm{p}$ ANCA in $94 \%$ of patients (95\% CI 86-99, $\mathrm{I}^{2}=35 \%$ ). The prevalence of anti-MPO antibodies was $93 \%$ (95\% CI $\left.83-99, \mathrm{I}^{2}=52 \%\right)$, that of anti-PR3 antibodies was $5 \%$
(95\% CI 1-11, $\mathrm{I}^{2}=0 \%$ ) (data from 8 studies) [11, 12, 25, 27-29].

\section{Induction therapies and drug-related adverse events}

Six studies reported the drugs used to induce remission $[11,25,27-30]$. In five of these studies, oral or intravenous cyclophosphamide was used with corticosteroids (62\%, $95 \%$ CI 20-96, I ${ }^{2}=90 \%$ ). In one study [30], only rituximab was used. If we excluded this study from the analysis, the prevalence of cyclophosphamide use increased to $77 \%$ (95 \% CI 45-99, I $\mathrm{I}^{2} 82 \%$ ). In one study [27], plasmapheresis was also performed. No detailed information about drug-related adverse events during follow-up was provided. One study stated that no cases of impaired fertility or cancer occurred during follow-up [29]. In another, only infections were described [30].

\section{Follow-up data for cumulative clinical manifestations, relapse, and survival}

Follow-up data were reported in seven articles [11, 12, 25, 27-30]. The duration of the observation period was reported in six studies, and ranged from 4 to 55 months. At least one relapse occurred in 25 to $50 \%$ of the patients (total of 63 patients from four studies) $[11,12,25,30]$. Twenty-nine patients (22 \%) developed end-stage renal disease or a need for dialysis during follow-up. All studies provided survival data. Six children died: one from the rupture of a hepatic aneurysm, one from pulmonary infection, one from cytomegalovirus infection, and no information was available for the other patients.

\section{Discussion}

We conducted this study to provide a better definition of the principal manifestations of childhood-onset GPA and MPA at presentation and their course over time. This study is the first to use a systematic approach including a meta-analysis to analyse these rare paediatric conditions for which a small number of essentially retrospective studies have been published to date.

We confirmed the female predominance of GPA and MPA in children. About $70 \%$ of the GPA patients and $80 \%$ of the MPA patients were girls. This finding contrasts with those for studies in adults, which have reported an absence of difference in frequency between the sexes or a slightly higher frequency in men for [31-33]. We also confirmed that most of these paediatric cases were diagnosed in adolescence.

As expected, the principal manifestations at disease onset were those involving the respiratory tract in patients with GPA and the kidney in patients with MPA. ENT involvement was rare in MPA, but was the most frequent clinical feature at presentation in GPA patients. It is, therefore, a potentially useful additional sign for distinguishing between these two conditions. Saddle 
Table 3 Main characteristics of the studies on childhood-onset microscopic polyangiitis and features of the patients at presentation

\begin{tabular}{|c|c|c|c|c|c|c|c|c|}
\hline First author & ludici [11] & Sacri [12] & Bakkaloglu [25] & Peco-Antic [27] & Basu [30] & Sun [29] & Hattori [26] & Yu [28] \\
\hline Speciality & $\begin{array}{l}\text { Adult Internal } \\
\text { Medicine }\end{array}$ & $\begin{array}{l}\text { Paediatric } \\
\text { Nephrology and } \\
\text { Rheumatology }\end{array}$ & $\begin{array}{l}\text { Paediatric Nephrology } \\
\text { and Rheumatology }\end{array}$ & Paediatric Nephrolology & $\begin{array}{l}\text { Paediatric } \\
\text { Nephrolology }\end{array}$ & $\begin{array}{l}\text { Paediatric } \\
\text { Nephrology }\end{array}$ & $\begin{array}{l}\text { Paediatric } \\
\text { Nephrology }\end{array}$ & $\begin{array}{l}\text { Paediatric } \\
\text { Nephrology }\end{array}$ \\
\hline Year of publication & 2015 & 2015 & 2001 & 2006 & 2015 & 2014 & 2001 & 2006 \\
\hline Years of enrolment & $1965-2014$ & $1986-2011$ & 1990-1999 & 1998-2003 & $2011-2014$ & $2003-2013$ & 1990-1997 & 1998-2004 \\
\hline Study design & Retrospective & Retrospective & Retrospective & Retrospective & Retrospective & Retrospective & Retrospective & Retrospective \\
\hline Number of patients & 4 & 38 & 10 & 7 & 11 & 20 & 21 & 19 \\
\hline Ethnicity & $\begin{array}{l}3 \text { Caucasian, } 1 \\
\text { Asian }\end{array}$ & 26 (68 \%) Caucasian & NA & NA & NA & NA & NA & NA \\
\hline Female, number (\%) & 0 & $34(89)$ & $6(60)$ & $6(86)$ & $6(54)$ & $16(80)$ & NA & $18(95)$ \\
\hline Median age at onset & NA & NA & NA & $12(7-15)$ & $7.6(4.3-11.8)$ & $10(1.9-16.8)$ & NA & $10.8 \pm 2.8$ \\
\hline Median age at diagnosis & $13(3-16)$ & $11.2(8.9-12.3)$ & $12(8-17)$ & NA & NA & NA & NA & NA \\
\hline $\begin{array}{l}\text { Classification/diagnostic } \\
\text { tool used }\end{array}$ & $\begin{array}{l}\text { Revised } \\
\text { Chapel-Hill }\end{array}$ & $\begin{array}{l}\text { According to Watts et } \\
\text { al. [40] }\end{array}$ & $\begin{array}{l}\text { Typical biopsy findings } \\
\text { for renal or non-renal } \\
\text { tissues }\end{array}$ & $\begin{array}{l}\text { Inclusion criteria: } \\
\text { 1) symptoms suggestive } \\
\text { of MPA; 2) Biopsy-proven } \\
\text { GN; 3) MPO-ANCA+ }\end{array}$ & $\begin{array}{l}\text { Revised Chapel- } \\
\text { Hill CC }\end{array}$ & $\begin{array}{l}\text { Revised Chapel- } \\
\text { Hill CC }\end{array}$ & Chapel-Hill & Chapel-Hill \\
\hline CANCA positivity (ELISA) & $1 / 1$ & $4 / 38$ & 0 & NA & 0 & $2 / 17$ & NA & 0 \\
\hline pANCA positivity (ELISA) & $0 / 1$ & $33 / 38$ & $10(100)$ & $7(100)$ & 11 & $16 / 17$ & NA & $19 / 19$ \\
\hline CANCA positivity (IFI) & $1 / 2$ & 0 & 0 & NA & 0 & $2 / 20$ & NA & 0 \\
\hline pANCA positivity (IFI) & $1 / 2$ & NA & $9(90)$ & NA & $10 / 10$ & $18 / 20$ & NA & $19 / 19$ \\
\hline \multicolumn{9}{|l|}{ Clinical manifestations } \\
\hline Systemic & $4(100.0)$ & $29(78.0)$ & $10(100.0)$ & $7(100.0)$ & $8(72.7)$ & $10(50.0)$ & $18(85.7)$ & $12(63.1)$ \\
\hline Mucocutaneous & $2(50.0)$ & $13(34.2)$ & $7(70.0)$ & $7(100.0)$ & $3(27.2)$ & $3(15.0)$ & $8(38.0)$ & $6(31.5)$ \\
\hline Musculoskeletal & $2(50.0)$ & $11(28.9)$ & $6 / 9(66.7)$ & $7(100.0)$ & $11(100.0)$ & $2(10.0)$ & $7(33.0)$ & 0 \\
\hline Ocular & 0 & $3(7.8)$ & 0 & 0 & 0 & $1(5.0)$ & $2(9.5)$ & $1(5.2)$ \\
\hline Ear, nose, and throat & 0 & 0 & 0 & 0 & 0 & 0 & $2(9.5)$ & $2(10.5)$ \\
\hline Respiratory & 0 & $11(28.9)$ & $3(30.0)$ & $4(57.1)$ & $5(45.4)$ & $3(15.0)$ & $13(61.9)$ & $10(52.6)$ \\
\hline Cardiovascular & $1(25.0)$ & 0 & 0 & 0 & $1(9.0)$ & 0 & 0 & 0 \\
\hline Gastrointestinal & $2(50.0)$ & $4(10.5)$ & 2/9 (22.2) & $4(57.1)$ & $2(18.1)$ & $3(15.0)$ & $7(33.3)$ & $9(47.3)$ \\
\hline Neurological & $2(50.0)$ & $2(5.2)$ & 2/9 (22.2) & $6(85.7)$ & $1(9.0)$ & $3(15.0)$ & $1(4.7)$ & $1(5.2)$ \\
\hline Renal & $4(100.0)$ & $36(94.7)$ & $7(70.0)$ & $7(100)$ & $11(100.0)$ & $16(100.0)$ & $21(100.0)$ & $19(100.0)$ \\
\hline
\end{tabular}

NA not available, ELISA enzyme-linked immunosorbent assay, IFI indirect immunofluorence 


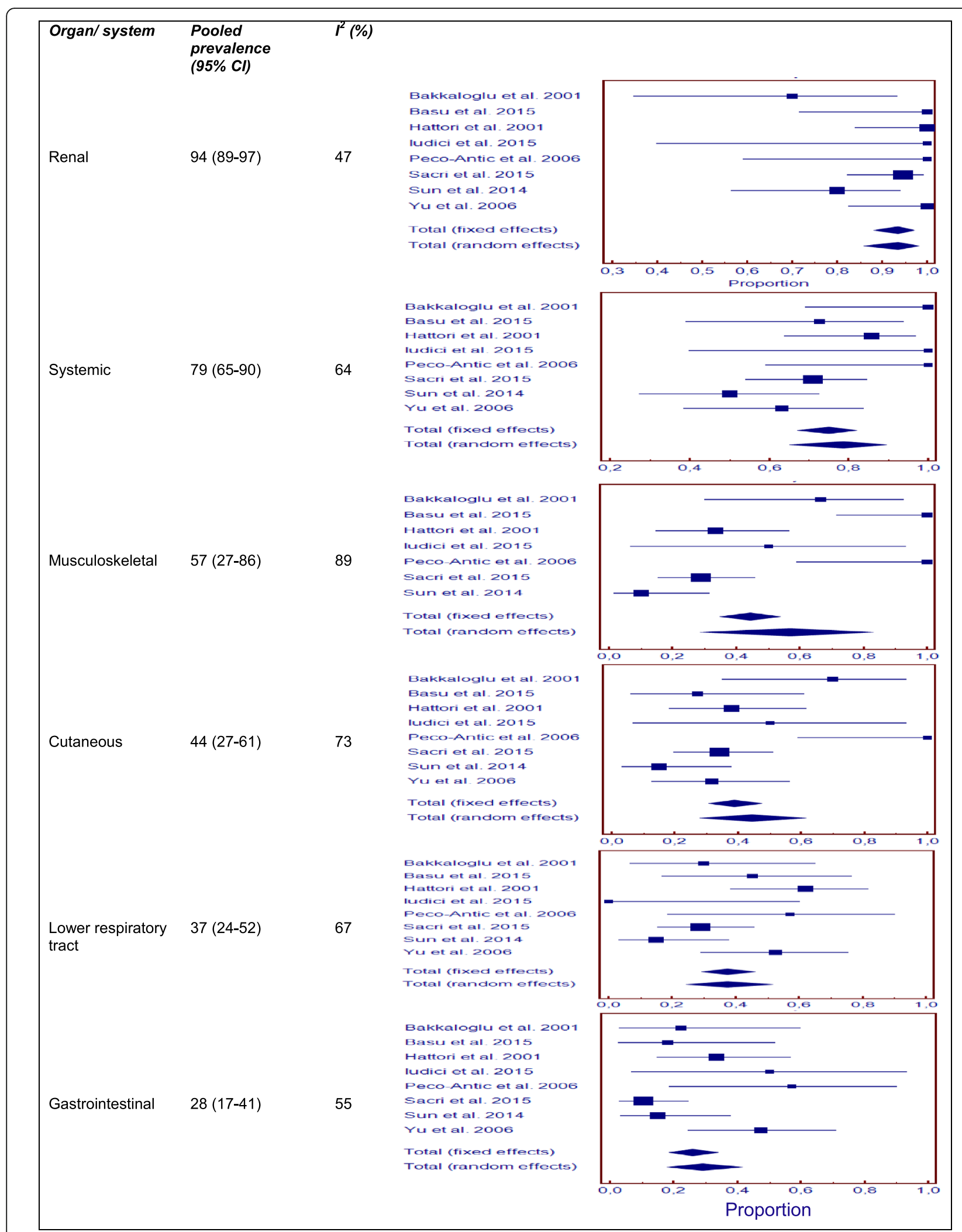

Fig. 2 Pooled prevalence for the most frequent organ/system involvement at first consultation in childhood-onset microscopic polyangiitis 
nose was already present at presentation in $5 \%$ of GPA patients, confirming previous observations of a higher rate of this complication in children [20, 23, 32]. Sinusitis was the only ENT feature observed in patients with MPA.

Renal disease was the leading feature of MPA, and was observed at onset in almost all children. However, as most of the surveys included were carried out at nephrology centres, there may have been a referral bias. As for GPA, the data from the different cohorts were highly heterogeneous, but renal impairment was diagnosed in about $65 \%$ of patients at presentation. This observation suggests that childhood GPA, when diagnosed, is a multisystem disease rather than a condition "limited" to the upper airways, as proposed in the past [23, 34]. In addition, renal disease is not very common at presentation in adults (17 \% of patients in the study by Hoffman et al. [31]) but it generally occurs during the course of the disease. By contrast, it seems to have a much higher incidence at disease onset in children. Moreover, one fifth of the children with MPA displayed progression to ESRD (end-stage renal disease) or a need for dialysis during follow-up, highlighting the severity of renal disease in these children.

In addition to the principal specific manifestations observed at presentation in GPA and MPA patients, systemic features were also frequent in three-quarters of patients at presentation and half the patients presented musculoskeletal symptoms, as also highlighted by a recently published study by the ARChiVe Investigator Network [35]. Eye problems were rare, but were more frequent in GPA than in MPA, whereas gastrointestinal involvement was more frequent in MPA than in GPA patients. Cardiomyopathy was described in only two patients, both with MPA.

Special attention should be paid to alveolar haemorrhage and subglottic stenosis, which may be life-threatening. Alveolar haemorrhage was not rare at disease presentation in either MPA or GPA, being observed in about $18 \%$ of patients. Subglottic stenosis was observed only in GPA patients. Early reports suggested that the incidence of subglottic stenosis was higher in children with GPA than in adults. Rottem et al. [23] found that about $40 \%$ of patients developed subglottic stenosis during 8 years of follow-up, corresponding to rates five times higher than reported in adult surveys [23]. These data, together with those from a UK cohort [20], led to the inclusion of subglottic stenosis in the paediatric classification criteria [4]. Our results give a more precise estimate of the impact of this complication on the course of paediatric GPA. The available data show that a fairly uniform proportion of paediatric cases (9 \%) already display subglottic stenosis at presentation. By contrast, incidence was found to vary considerably over time. Cumulative incidence ranged from $16 \%$ [11] to $40-48 \%$ in studies with similar follow-up periods [8, 20, 23]. Overall, these data confirm the previous finding of a higher risk of subglottic stenosis in children than in adults, in whom a cumulative prevalence of $10 \%$ has been reported [36].

A large proportion of the patients tested detected positive for ANCA. Only one MPA patient with anti-PR3 antibodies was reported. However, one fifth of the GPA patients tested positive for anti-MPO antibodies, and this proportion was similar in all studies. The high prevalence of ANCA in children as compared to adults should be borne in mind when paediatricians are considering a diagnosis of one of these diseases.

A number of different treatment regimens were used, but the drugs used to treat GPA differed little between studies, reflecting a relatively uniform approach to the induction of remission over the long time period covered by this meta-analysis. Most of the information about treatment provided by the available reports concerned "traditional" drugs, with rituximab treatment reported in only one patient. This is consistent with the approval of rituximab registration for induction treatment in adult patients with GPA and MPA by the FDA in 2011 and by the EMA in 2013. Reports pointing out a good response to rituximab are rapidly increasing. Cyclophosphamide was the drug most frequently used to treat patients with MPA, and a protocol based on rituximab and mycophenolate mofetil was considered as a first-line treatment in only one study, on 11 patients [30]. In this study, $90 \%$ of the patients were in complete remission at the last follow-up visit.

The paucity of available information made it impossible to define the course of the disease with any degree of precision. For example, a detailed assessment of disease activity over time is lacking. This could have been favoured by the delay in drawing up a specific index for paediatric conditions [37]. However, the available data suggest that most GPA patients experience at least one relapse, whereas disease flares are observed in less than half of all MPA patients. However, end-stage renal disease was a particular problem in children with MPA. About one fifth of the children with MPA presented ESRD, whereas the proportion of GPA patients presenting this condition was much lower. As in adults [38], the development of new therapeutic strategies should help to improve disease-free survival.

The burden of drug-related adverse effects was well described only in papers on GPA. The most frequent problems encountered were infections, followed by damage due to chronic corticosteroid and cyclophosphamide treatments. The data relating to growth retardation in GPA patients were inconsistent.

Overall, $7 \%$ of the patients for whom follow-up data were available died during follow-up, mostly from disease-related and infectious complications. Respiratory complications were the leading causes of disease-related death in children with GPA. These data confirm that 
8. Fowler NM, Beach JM, Krakovitz P, et al. Airway manifestations in childhood granulomatosis with polyangiitis (Wegener's). Arthritis Care Res (Hoboken). 2012;64:434-40

9. Bohm M, Gonzalez Fernandez Ml, Ozen S, et al. Clinical features of childhood granulomatosis with polyangiitis (Wegener's granulomatosis). Pediatr Rheumatol Online J. 2014;12:18.

10. Kosalka J, Bazan-Socha S, Ignacak M, et al. Clinical manifestation of pediatric granulomatosis with polyangiitis - the experience of two regions in Poland. Folia Med Cracov. 2014;54:5-12

11. Iudici M, Puéchal X, Pagnoux C, et al. Childhood-onset systemic necrotizing vasculitides: long-term data from the French vasculitis study group registry. Arthritis Rheumatol. 2015;67:1959-65.

12. Sacri AS, Chambaraud T, Ranchin B, et al. Clinical characteristics and outcomes of childhood-onset ANCA-associated vasculitis: a French nationwide study. Nephrol Dial Transplant. 2015;30 Suppl 1:i104-12.

13. Stroup DF, Berlin JA, Morton SC, et al. Meta-analysis of observational studies in epidemiology: a proposal for reporting. Meta-analysis of observational studies in epidemiology (MOOSE) group. JAMA. 2000;283:2008-12.

14. Hellmich B, Flossmann O, Gross WL, et al. EULAR recommendations for conducting clinical studies and/or clinical trials in systemic vasculitis: focus on anti-neutrophil cytoplasm antibody-associated vasculitis. Ann Rheum Dis. 2007;66:605-17.

15 Shamliyan TA, Kane RL, Ansari MT, et al. Development quality criteria to evaluate nontherapeutic studies of incidence, prevalence, or risk factors of chronic diseases: pilot study of new checklists. J Clin Epidemiol. 2011;64:637-57.

16 Sterne JA, Egger M, Smith GD. Systematic reviews in health care: investigating and dealing with publication and other biases in metaanalysis. BMJ. 2001;323:101-5.

17 Orlowski JP, Clough JD, Dyment PG. Wegener's granulomatosis in the pediatric age group. Pediatrics. 1978;61:83-90

18 Wong SN, Shah V, Dillon MJ. Antineutrophil cytoplasmic antibodies in Wegener's granulomatosis. Arch Dis Child. 1998;79:246-50.

19 Stegmayr BG, Gothefors L, Malmer B, et al. Wegener granulomatosis in children and young adults. A case study of ten patients. Pediatr Nephrol. 2000;14:208-13.

20 Belostotsky VM, Shah V, Dillon MJ. Clinical features in 17 paediatric patients with Wegener granulomatosis. Pediatr Nephrol. 2002;17:754-61.

21 Tahghighi F, Moradinejad MH, Aghighi Y, et al. Evaluation of 10-year experience of Wegener's granulomatosis in Iranian children. ISRN Rheumatol. 2013;2013:694928.

22 Gajic-Veljic M, Nikolic M, Peco-Antic A, et al. Granulomatosis with polyangiitis (Wegener's granulomatosis) in children: report of three cases with cutaneous manifestations and literature review. Pediatr Dermatol. 2013;30:e37-42.

23 Rottem M, Fauci AS, Hallahan CW, et al. Wegener granulomatosis in children and adolescents: clinical presentation and outcome. J Pediatr. 1993;122:26-31.

24 Stone JH, Hoffman GS, Merkel PA, et al. A disease-specific activity index for Wegener's granulomatosis: modification of the Birmingham vasculitis activity score. International network for the study of the systemic vasculitides (INSSYS). Arthritis Rheum. 2001:44:912-20.

25 Bakkaloglu A, Ozen S, Baskin E, et al. The significance of antineutrophil cytoplasmic antibody in microscopic polyangitis and classic polyarteritis nodosa. Arch Dis Child. 2001;85:427-30.

26 Hattori M, Kurayama H, Koitabashi Y, et al. Antineutrophil cytoplasmic autoantibody-associated glomerulonephritis in children. J Am Soc Nephrol. 2001:12:1493-500

27 Peco-Antic A, Bonaci-Nikolic B, Basta-Jovanovic G, et al. Childhood microscopic polyangiitis associated with MPO-ANCA. Pediatr Nephrol. 2006;21:46-53.

28 Yu F, Huang JP, Zou WZ, et al. The clinical features of anti-neutrophil cytoplasmic antibody-associated systemic vasculitis in Chinese children. Pediatr Nephrol. 2006;21:497-502.

29 Sun L, Wang $H_{\text {, Jiang } X}$, et al. Clinical and pathological features of microscopic polyangiitis in 20 children. J Rheumatol. 2014;41:1712-9.

30 Basu B, Mahapatra TK, Mondal N. Favourable renal survival in paediatric microscopic polyangiitis: efficacy of a novel treatment algorithm. Nephrol Dial Transplant. 2015;30 Suppl 1:1113-8.

31 Hoffman GS, Kerr GS, Leavitt RY, et al. Wegener granulomatosis: an analysis of 158 patients. Ann Intern Med. 1992;16:488-98.

32 Bligny D, Mahr A, Toumelin PL, et al. Predicting mortality in systemic Wegener's granulomatosis: a survival analysis based on 93 patients. Arthritis Rheum. 2004:51:83-91.
33 Halstead LA, Karmody CS, Wolff SM. Presentation of Wegener's granulomatosis in young patients. Otolaryngol Head Neck Surg. 1986;94:368-71.

34 Hall SL, Miller LC, Duggan E, et al. Wegener granulomatosis in pediatric patients. J Pediatr. 1985;106:739-44.

35 Cabral DA, Canter DL, Muscal E, et al. Comparing presenting clinical features of 48 children with microscopic polyangiitis (MPA) against 183 having granulomatosis with polyangiitis (GPA). An ARChiVe study. Arthritis Rheumatol. 2016. [Epub ahead of print].

36 Lebovics RS, Hoffman GS, Leavitt RY, et al. The management of subglottic stenosis in patient with Wegener's granulomatosis. Laryngoscope. 1992;102: 1341-5.

37 Dolezalova P, Price-Kuehne FE, Özen S, et al. Disease activity assessment in childhood vasculitis: development and preliminary validation of the paediatric vasculitis activity score (PVAS). Ann Rheum Dis. 2013;72:1628-33.

38 Puéchal X, Pagnoux C, Perrodeau É, et al. Long-term outcomes among participants in the WEGENT trial of remission-maintenance therapy for granulomatosis with polyangiitis (Wegener's) or microscopic polyangiitis. Arthritis Rheumatol. 2016;68:690-701.

39 Navon Elkan P, Pierce SB, Segel R, et al. Mutant adenosine deaminase 2 in a polyarteritis nodosa vasculopathy. N Engl J Med. 2014;370:921-31.

40 Watts R, Lane S, Hanslik T, et al. Development and validation of a consensus methodology for the classification of the ANCA-associated vasculitides and polyarteritis nodosa for epidemiological studies. Ann Rheum Dis. 2006;66: $222-7$.

\section{Submit your next manuscript to BioMed Central and we will help you at every step:}

- We accept pre-submission inquiries

- Our selector tool helps you to find the most relevant journal

- We provide round the clock customer support

- Convenient online submission

- Thorough peer review

- Inclusion in PubMed and all major indexing services

- Maximum visibility for your research

Submit your manuscript at www.biomedcentral.com/submit 